\title{
EFFECT OF CURCUMA XANTHORRHIZA ROXB. ETHANOL EXTRACT ON THE VIABILITY OF STREPTOCOCCUS MUTANS AND STREPTOCOCCUS SANGUINIS DUAL-SPECIES BIOFILMS
}

\author{
FARIDA ERVINTARI, RIA PUSPITAWATI*, SRI UTAMI
}

\author{
Department of Oral Biology, Faculty of Dentistry, Universitas Indonesia, Jakarta, Indonesia. Email: rpuspitawati2013@gmail.com
}

Received: 30 September 2018, Revised and Accepted: 22 February 2019

ABSTRACT

Objective: This study aimed to determine the effect of ethanol Curcuma extract on the viability of S. mutans and Streptococcus sanguinis in a dualspecies in vitro biofilm model.

Methods: Dual-species biofilms of S. mutans and S. sanguinis were exposed to ethanol Curcuma extract at various concentrations. The sample of saliva was gathered from healthy volunteers. Chlorhexidine $0.2 \%$ was used as a positive control, and bacterial culture without intervention served as a negative control. The total suspensions of $10^{-\alpha \sigma}$ were prepared for S. mutans and S. sanguinis cells. The bacteria were incubated for $20 \mathrm{~h}$ (active maturation phase) and $24 \mathrm{~h}$ (maturation phase).

Results: The result showed decreased $S$. mutans and S. sanguinis viability after exposure to $0.2 \%-25 \%$ Curcuma ethanol extracts during the active accumulation and maturation phases. The decrease in bacterial viability was significantly different in all concentrations of Curcuma ethanol extracts compared with negative controls $(\mathrm{p}<0.05)$ in the active accumulation and maturation phases.

Conclusion: Temulawak ethanol extract (starting at $0.2 \%$ ) can decrease the viability of S. mutans and S. sanguinis in a dual species in vitro biofilm model during the accumulation and maturation phases.

Keywords: Dual species, Curuma xanthorriza ethanol extract, Streptococcus mutans, Streptococcus sanguinis, Viability.

(C) 2019 The Authors. Published by Innovare Academic Sciences Pvt Ltd. This is an open access article under the CC BY license (http://creativecommons. org/licenses/by/4. 0/) DOI: http://dx.doi.org/10.22159/ijap.2019.v11s1.181

\section{INTRODUCTION}

Dental caries is a disease of the tooth tissue, enamel, dentin, and cementum caused by the activity of microorganisms on fermented carbohydrates. The formation of caries is characterized by demineralization of tooth tissue, followed by the breakdown of organic components. Bacterial invasion of caries damages the pulp tissue and spreads the infection to the periapical tissue and cause pain [1]. According to Keyes and Jordan, three main factors contribute to caries: A host, a substrate (diet), and an agent (microorganism). Time (duration) is another important contributing factor [2,3]. Caries occurs when all three factors are present and work simultaneously over a period of time [1].

A biofilm is an aggregation of microorganisms attached to a surface and covered by extracellular polysaccharides that are a major component of biofilms and assist in maintaining biofilm structures [4]. There are various species within natural biofilms that communicate through quorum sensing and affect each other, either synergistically or antagonistically [5]. The formation of biofilms in the oral cavity can be divided into three phases: Adhesion, active accumulation, and maturation. The adhesion phase is the initial stage of biofilm formation involving an adhesive attachment, which is a thin protein film derived from salivary glycoproteins. The adhesion is related to the interaction between oral bacteria and the host molecules. The active accumulation phase occurs after the pioneer bacteria are attached, and the early colonizing bacteria (pioneer colonizers) provide a place for the next bacteria to colonize either directly or through salivary glycoproteins. Furthermore, colonializing bacteria recognize polysaccharides or receptor proteins on the surface of pioneer and attached bacterial cells. During the maturation phase, bacterial growth slows down or stops due to limited nutrients. The bacteria will leave the biofilm by separating from a single cell or a group of cells $[6,7]$.
Bacterial competition is common in biofilms, in which these bacteria compete for nutrients, attachment, and survival. Certain bacteria within biofilms express nonspecific proteins (e.g., bacteriocin) that can affect other bacteria. Production of organic acids is one of the competitive mechanisms of Streptococcus mutans in inhibiting Streptococcus sanguinis. S. mutans produces more acid than $S$. sanguinis due to the high activity of ATP-glucose phosphotransferase in $S$. mutans. Therefore, lactic acid produced by $S$. mutans is excreted into the environment and inhibits the growth of S. sanguinis. Therefore, S. mutans increases in number compared with S. sanguinis. S. mutans also inhibits S. sanguinis with Mutasin I and IV. Mutasin can enhance the competitiveness of $S$. mutans in colonization and its ability to develop biofilms. In a third inhibitory mechanism, S. mutans inhibits the ability of $S$. sanguinis to produce hydrogen peroxide [4].

Primary prevention is a precautionary procedure before the onset of disease. A primary prevention measure against dental caries is using chlorhexidine as a mouthwash. Although chlorohexidine has broad and potent antimicrobial effects, it also has long-term side effects such as staining the teeth and disturbing the ecology of oral bacteria [8].

Curcuma xanthorrhiza Roxb. (temulawak) is a plant found in various parts of Indonesia that has been established by the Food and Drug Supervisory Agency (BADAN POM) as one of the leading medicinal plants $[9,10]$. Curcuma is also used an ingredient in almost all types of traditional medicine in Indonesia [11]. In general, using traditional medicine is considered safer than using synthetic drugs because traditional medicine has relatively fewer side effects than synthetic drugs [12]. The use of Curcuma has progressed, starting from the preparation of traditional medicine and developed into standardized herbal drugs, which can then become phytopharmaca preparations [11].

Curcuma rhizomes contain 48\%-59.64\% starch, 1.6\%-2.2\% curcumin, and $1.48 \%-1.63 \%$ essential oils [13]. These three components serve 
as the most important secondary metabolites that are beneficial for health, in industry, and household $[14,15]$. In addition to these three components, Curcuma contains protein, fat (fixed oil), cellulose, and minerals [14]. Curcuma has also been widely reported to be useful as an antimicrobial and anti-inflammatory compound [13].

One of the active components of essential oils in Curcuma that has an antibacterial effect is xanthorrhizol. According to Hwang's research, isolation of xanthorrhizol from Curcuma rhizomes has a high anticarcinogenic activity against oral pathogens. Xanthorrhizol exhibits the highest antibacterial activity against Streptococcus species that cause dental caries and also exhibits antibacterial potency against Actinomyces viscosus and Porphyromonas gingivalis, which cause periodontitis. Moreover, xanthorrhizol acts as an antibacterial agent to inhibit and eliminate $S$. mutans biofilms [16]. This antibacterial activity is thought to arise from phenol compounds in the Curcuma extract. Hydrogen bonds form between hydroxyl groups in the phenol compounds with cell membrane proteins, disrupting membrane permeability, and resulting in cell death. The coagulation of proteins and lysis of cell membranes result from the penetration of high amounts of phenol into cells $[17,18]$. Previous studies have shown that xanthorrhizol can destroy the integrity of cell walls. Xanthorrhizol exposure damages the peptidoglycan layer of $S$. mutans, causing leakage of intracellular contents and subsequent cell death [19].

A study by Rahmawati at the Faculty of Dentistry Universitas Indonesia reported that the viability of $S$. mutans biofilms decreased with increasing concentrations of ethanol Curcuma extract during the active accumulation phase $(20 \mathrm{~h})$ and maturation phase (24 h) [20]. Similarly, a study conducted by Fidinina (2011) demonstrated that ethanol Curcuma extract at a concentration of $0.5 \%-5 \%$ can decrease $S$. sanguinis viability in both the active accumulation and the maturation phases [21].

Based on the results of previous research on the effect of ethanol extract on the viability of single-species biofilms, this study aimed to determine the effect of ethanol Curcuma extract on the viability of $S$. mutans and $S$. sanguinis in a dual species in vitro biofilm model. It is well known that when growing as a dual species biofilm, these two bacteria compete with each other due to the limited space and nutrient availability. There is also an antagonistic relationship between S. mutans and S. sanguinis when grown simultaneously.

\section{METHODS}

Dual species biofilms of $S$. mutans and S. sanguinis were exposed to ethanol Curcuma extract at various concentrations. Curcuma ethanol extract was obtained by the maceration method derived from the Indonesian Medicinal and Aromatic Crops Research Institute (BALLITRO), Bogor. Chlorhexidine $0.2 \%$ was used as a positive control, and bacterial culture without intervention served as a negative control. Suspensions of $10^{-5} S$. mutans and $S$. sanguinis cells were prepared. To create the biofilm model, the first saliva coating was applied to 96-well plates to obtain the pellicle. Saliva was obtained from healthy volunteers. After pellicle formation, the plates were washed with as much as $100 \mu \mathrm{l}$ of phosphate buffer solution (PBS), and suspensions of $50 \mu \mathrm{l}$ of $S$. mutans and $50 \mu \mathrm{l}$ of $S$. sanguinis were added. The bacteria were incubated for $20 \mathrm{~h}$ (active maturation phase) and $24 \mathrm{~h}$ (maturation phase).

Following incubation, $100 \mu \mathrm{l}$ of Curcuma ethanol extract was added at $0.2 \%, 1 \%, 5 \%, 10 \%, 15 \%, 20 \%$, and $25 \%$ concentrations. As a positive control, $100 \mu \mathrm{l}$ of $0.2 \%$ chlorhexidine was used. As a negative control, S. mutans and S. sanguinis were not exposed to Curcuma ethanol extract or $0.2 \%$ chlorhexidine, but $100 \mu \mathrm{l}$ of brain heart infusion broth was added. After $1 \mathrm{~h}$ of incubation, cells were washed with $100 \mu \mathrm{l}$ of PBS $(5 \mathrm{mg} / \mathrm{ml}$ ) solution and incubated for $2.5 \mathrm{~h}$. Acidified isopropanol solution $(100 \mu \mathrm{l})$ was added to each well, and plates were placed on top of the orbital shaker for $1 \mathrm{~h}$. Finally, the optical density (OD) values were read on a microplate reader at $490 \mathrm{~nm}$.
Bacterial viability was analyzed by Shapiro-Wilk and KruskalWallis tests. The Shapiro-Wilk test was used to test the normality of data distribution. Then, a non-parametric Kruskal-Wallis test was performed to determine whether there was a significant difference among treatment groups, and a post hoc analysis was performed with Mann-Whitney U-test.

\section{RESULTS}

The results of the MTT assay during the active accumulation phase $(20 \mathrm{~h})$ are presented in Table 1 . MTT assay results during the maturation phase ( $24 \mathrm{~h}$ ) are presented in Table 2 . A summary of results during both phases are presented in Table 3.

The Kruskal-Wallis test showed decreased S. mutans and S. sanguinis viability after exposure to $0.2 \%-25 \%$ Curcuma ethanol extracts during the active accumulation and maturation phases. The decrease in bacterial viability was significantly different in all concentrations of Curcuma ethanol extracts compared with negative controls $(\mathrm{p}<0.05)$ in the active accumulation and maturation phases. Chlorhexidine $(0.2 \%)$ as a positive control also significantly decreased the viability of the bacteria compared with the negative control. The effects of Curcuma ethanol extracts did not significantly differ from those of $0.2 \%$ chlorhexidine. In addition, bacterial viability in the maturation phase tended to be higher than that in the active accumulation phase. However, the Kruskal-Wallis test indicated that this result was not significant $(\mathrm{p}=0.377)$; hence, a post hoc test was not performed.

\section{DISCUSSION}

This study showed that the viability of the S. mutans and S. sanguinis dual species biofilm significantly decreased when exposed to Curcuma ethanol extract $(0.2 \%)$ compared with negative control. There was an increase in the percentage of bacterial viability after exposure to Curcuma ethanol extract at concentrations of $1 \%, 5 \%$, and $10 \%$. However, the increased bacterial viability was still lower than that of the negative controls. These results showed that the effects of ethanol Curcuma extract on the viability of $S$. mutans and $S$. sanguinis are independent of their concentration. It is possible that the yellow color of a curcuminoid and high viscosity of Curcuma ethanol extracts can influence the viability of the dual species Streptococcus using the MTT test, thus causing inaccuracy in the reading of OD values. It is also possible that decreased viability of the dual species Streptococcus biofilm occurs only at low Curcuma concentrations.

The decrease in the viability of the dual species Streptococcus biofilm is likely due to the antibacterial activity of xanthorrhizol, which consists of phenol and hydrocarbon chains. The hydroxyl group is the main active antibacterial component. There are two mechanisms of anticaries metabolism of natural antimicrobial agents. The first mechanism is to destroy the integrity of the cell wall, and the second mechanism is to inhibit the process of bacterial adhesion in biofilm formation. Xanthorrhizol can destroy the integrity of cell walls. S. mutans exposed to Curcuma incurs damage to its peptidoglycan layer, causing leakage of intracellular contents and cell death.

The results of this study also showed that bacterial viability tended to decrease more during the active accumulation phase $(20 \mathrm{~h})$ than the maturation phase $(24 \mathrm{~h})$ when exposed to temulawak ethanol extract. This finding was expected because almost all antimicrobials are effective at killing rapidly growing cells (active accumulation phase). Slow growth during the maturation phase is a factor that causes cell resistance against antimicrobials from Curcuma ethanol extract.

This study also showed that there was no significant difference between the viability of dual species biofilms exposed to chlorhexidine $0.2 \%$ and those exposed to ethanol Curcuma extracts of various concentrations. This finding demonstrated that Curcuma ethanol extract has potential as an antibacterial compound against $S$. mutans and $S$. sanguinis dual species biofilms, even at a low concentration of $0.2 \%$. However, the 
Table 1: Effect of Curcuma ethanol extract on the viability of Streptococcus mutans and Streptococcus sanguinis during the active accumulation phase $(20 \mathrm{~h})$

\begin{tabular}{|c|c|c|c|}
\hline Concentration (\%) & Viability (\%) & p value to the negative control & p value to the positive control \\
\hline Negative control (BHI broth) & 100 & & 0.037 \\
\hline 0.20 & 18.049 & 0.037 & 0.127 \\
\hline 1 & 31.788 & 0.037 & 0.050 \\
\hline 5 & 41.494 & 0.037 & 0.050 \\
\hline 10 & 49.787 & 0.037 & 0.050 \\
\hline 15 & 33.315 & 0.037 & 0.050 \\
\hline 20 & 28.856 & 0.037 & 0.050 \\
\hline Positive control (chlorhexidine 0.2) & 3.664 & 0.037 & \\
\hline
\end{tabular}

BHI: Brain heart infusion

Table 2: Effect of Curcuma ethanol extract on the viability of Streptococcus mutans and Streptococcus sanguinis during the maturation phase (24 h)

\begin{tabular}{|c|c|c|c|}
\hline Concentration (\%) & Viability (\%) & $p$ value to the negative control & $p$ value to the positive control \\
\hline Negative control (BHI broth) & 100 & & 0.037 \\
\hline 0.20 & 24.409 & 0.037 & 0.050 \\
\hline 1 & 28.925 & 0.037 & 0.050 \\
\hline 5 & 45.198 & 0.037 & 0.127 \\
\hline 10 & 60.646 & 0.037 & 0.050 \\
\hline 15 & 59.535 & 0.037 & 0.050 \\
\hline 20 & 41.793 & 0.037 & 0.513 \\
\hline 25 & 33.262 & 0.037 & 0.513 \\
\hline Positive control (chlorhexidine 0.2) & 7.671 & 0.037 & \\
\hline
\end{tabular}

BHI: Brain heart infusion

Table 3: Effect of Curcuma ethanol extract on the viability of Streptococcus mutans and Streptococcus sanguinis during the active accumulation phase $(20 \mathrm{~h})$ and maturation phase $(24 \mathrm{~h})$

\begin{tabular}{lll}
\hline Concentrations of extracts (\%) & Viability at active accumulation phase (\%) & Viability at maturation phase (\%) \\
\hline Negative control (BHI broth) & 100 & 100 \\
0.20 & 18.049 & 24.409 \\
1 & 31.788 & 28.925 \\
5 & 41.494 & 45.198 \\
10 & 49.787 & 60.646 \\
15 & 33.315 & 59.535 \\
20 & 28.856 & 41.793 \\
25 & 28.572 & 33.262 \\
Positive control (chlorhexidine 0.2$)$ & 3.664 & 7.671 \\
\hline
\end{tabular}

BHI: Brain heart infusion

antibacterial effect of curcuma extract at concentrations of $0.2 \%-25 \%$ did not show better effectiveness than $0.2 \%$ chlorhexidine. Findings were similar between the maturation phase $(24 \mathrm{~h})$ and the active accumulation phase.

\section{CONCLUSION}

We observed that temulawak ethanol extract (starting at $0.2 \%$ ) can decrease the viability of $S$. mutans and $S$. sanguinis in a dual species in vitro biofilm model during the accumulation and maturation phases. The antibacterial effect of temulawak ethanol extract was effective during the active accumulation phase.

\section{CONFLICTS OF INTEREST}

None declared.

\section{REFERENCES}

1. Pintauli S, Hamada T. Heading to better oral health. [Menuju gigi dan mulut sehat]. Medan: USU Press; 2008. p. 4-8.

2. Keyes PH, Jordan HV. Factors influencing initiation, transmission and inhibition of dental caries. In: Harris RJ, editor. Mechanisms of Hard Tissue Destruction. New York: Academic Press; 1963. p. 261-83.

3. Samaranayake L. Essential Microbiology for Dentistry. $3^{\text {rd }}$ ed.
Philadelphia. PA: Churchill Livingstone; 2006. p. 115-25.

4. Huang R, Li M, Gregory RL. Bacterial interactions in dental biofilm. Virulence 2011;2:435-44.

5. Burmølle M, Webb JS, Rao D, Hansen LH, Sørensen SJ, Kjelleberg S, et al. Enhanced biofilm formation and increased resistance to antimicrobial agents and bacterial invasion are caused by synergistic interactions in multispecies biofilms. Appl Environ Microbiol 2006;72:3916-23.

6. Prescott LM, Harley JP, Klein DA. Microbiology. Boston: Mc GrawHill; 2002. p. 620-2.

7. Nisengard RJ, Newman MG. Oral Microbiology and Immunology. $2^{\text {nd }}$ ed. United States of America: WB Saunders Company; 1994. p. 34-7.

8. Angela A. Primary prevention for children with high risk dental caries [Pencegahan primer pada anak yang berisiko karies tinggi]. Dent J (Maj Ked Gigi) 2005;38:130-4.

9. Rahardjo MO. Implementation of operational procedure standard to support temulawak as a potential basic material of drug [Penerapan SOP budidaya untuk mendukung temulawak sebagai bahan baku obat potensial]. Perspektif 2010;9:78-93.

10. National Agency of Drug and Food Control of Republic of Indoesia [Badan Pengawas Obat Dan Makanan]. Criteria and Guideline to Register Traditional Medicine, Standardization of Herbal Drugs, and Phytopharmacy [Kriteria Dan Tata Laksana Pendaftaran Obat Tradisional, Obat Herbal Terstandar Dan Fitofarmaka]. Jakarta: Badan 
Pengawas Obat Dan Makanan; 2005.

11. Yusron MU. Curcuma xanthorrhiza Roxb's response towards bio fertilizer in different condition of agroecology [Respon temulawak (Curcuma xanthorrhiza Roxb) terhadap pemberian pupuk bio pada kondisi agroekologi yang berbeda]. J Litt 2009;15:162-7.

12. Sari LO. The utilization of traditional medicine with considering the advantage and the safety [Pemanfaatan obat tradisional dengan pertimbangan manfaat dan keamanannya]. Pharm Sci Res 2012;3:1-7.

13. Mangunwardoyo W. Antimicrobial and identification of active compound Curcuma xanthorrhiza Roxb. IJBAS-IJENS 2012;12:69-78.

14. Salleh NA, Ismail S, Halim MR. Effects of Curcuma xanthorrhiza Extracts and their constituents on phase II drug-metabolizing enzymes activity. Pharm Res 2016;8:309-15

15. Utami A, Meryalita R, Prihatin AN, Ambarsari L, AsriKurniatin P, Nurcholis W. The Variation of Curcuma xanthorrhiza Roxb 's Leaves DNA Isolation [Variasi Metode Isolasi DNA Daun Temulawak (Curcuma xanthorrhiza Roxb.)]. Bogor: Department of Biochemistry FMIPA IPB; 2012.

16. Hwang JK, Rukayadi Y. Challenges and Opportunities in Applying Temulawak (Curcuma xanthorrhiza Roxb.) for Industrial Oral Care Products. Indonesia: Proceeding National Conference of National Indonesian Chemical Association [Prosiding Seminar Nasional
Himpunan Kimia Indonesia]; 2006. p. 25-32.

17. Hertiani T, Palupi SI, Nurwindasari DH. Antimicrobial test of Staphylococcus aureus, Eschericia coli, Shygella dysentriae and Candida albicans from traditional medicine to infectious diseases [Uji In vitro antimikroba terhadap Staphylococcus aureus, Eschericia coli, Shygella dysentriae dan Candida albicans Dari Beberapa Tanaman Obat Tradisional Untuk Penyakit Infeksi]. J Farm Indon Pharm 2003;4:89-95

18. Parwata IM, Dewi PF. Isolation and antibacterial activity of Alpinia galanga L [Isolasi dan uji aktivitas antibakteri minyak atsiri dari rimpang lengkuas (Alpinia galanga L.)]. J Kimia 2008;2:100-4.

19. Kim JE, Kim HE, Hwang JK, Lee HJ, Kwon HK, Kim BI, et al. Antibacterial characteristics of Curcuma xanthorrhiza extract on Streptococcus mutans biofilm. J Microbiol 2008;46:228-32.

20. Rahmawati R. Antibacterial Effect of Ethanol Extract Towards Viability of Streptococcus mutans [Efek antibakteri ekstrak etanol temulawak terhadap viabilitas Streptococcus mutans dalam biofilm [Thesis]. Jakarta: Faculty of Dentistry, Universitas Indonesia; 2011

21. Fidinina N. Efek Ekstrak Etanol Temulawak Terhadap Viabilitas Streptococcus sanguinis Berdasarkan Uji Crystal Violet (in vitro) [Thesis]: Faculty of Dentistry, Universitas Indonesia; 2011. 